\title{
Variation of Monoterpenoid Content among Subspecies and Accessions of Artemisia tri- dentata Grown in a Uniform Garden
}

\author{
BRUCE L. WELCH AND E. DURANT MCARTHUR
}

\section{Abstract}

We discovered that the midwinter monoterpenoid (volatile or essential oils) content of $\boldsymbol{A}$. tridentata is under genetic control. We base this conclusion on the results of our study which demonstrated that some accessions of $\boldsymbol{A}$. tridentata, grown under uniform conditions, contained significantly higher levels of monoterpenoids than others. The relationship between monoterpenoids, digestion, and palatability has not yet been conclusively demonstrated. If monoterpenoids interfere with digestion or have a negative impact on palatability, breeding and selection schemes can be developed to capitalize on the significant variation that exists among accessions of $\boldsymbol{A}$. tridentata. Superior strains of $\boldsymbol{A}$. tridentata could then be developed for use on mule deer winter ranges.

The health and vigor of microorganisms in mule deer rumen is paramount to the well-being of the deer. Rumen microbial activity through production of volatile fatty acid accounts for the major source of digestible energy for mule deer (Maynard and Loosli 1962). Any material which reduces rumen microbial activity would cause a reduction in the volatile fatty acids and thus a drop in digestible energy. Several studics have demonstrated possible harmful effects of monoterpenoids (volatile or essential oils) and, in particular, the oxygenated monoterpenoids on rumen microorganisms (Nagy et al. 1964; Oh et al. 1967; et al. 1968; and Longhurst et al. 1969). One way to improve nutritional value of $A$. tridentata would be to lower the monoterpenoid content. This may be possible if significant genetic variation exists among accessions of $A$. tridentata. We undertook this study to determine the variation of monoterpenoid content among subspecies and accessions of $A$. tridentata grown under uniform conditions.

\section{Materials and Methods}

From a uniform shrub garden at the Snow field Station ${ }^{1}$ at Ephraim, Utah, 20 accessions (Table 1) of $A$. tridentata (big sagebrush) were selected to study the variation of the midwinter monoterpenoid content. Of these accessions, 10 were $A$. tridentata ssp. vaseyana, seven were $A$. tridentata ssp. tridentata, and three were A. tridentata ssp. wyomingensis. Subspecies were identified by morphological criteria (Beetle and Young 1965; Winward and Tisdale 1977; McArthur et al. 1979), and chemical criteria (Stevens and McArthur 1974). Within each accession, five plants were selected at random. Vegetative samples of current-year leaves and stems were collected randomly over the entire crown of each plant. This collecting was accomplished on January 18, 1978. Tissue (leaves and stems) collected from a given plant was placed in a paper bag and frozen on-site with dry ice. All samples were collected within a 90 -minute period (10:00-11:30 a.m.) to avoid diur-

Authors are research plant physiologist and research geneticist, Intermountain Forest and Range Experiment Station, Forest, U.S. Department of Agriculture, Ogden, Utah 84401; located at Shrub Sciences Laboratory Provo, Utah 84601

Manuscript received December 8, 1979.

\footnotetext{
The shrub garden is cooperatively maintained by Snow College, Utah State University, Utah Division of Wildlife Resources (W-52-R) and the Intermountain Forest and Range Experiment Station.
}

Table 1. Locations of 20 accessions of big sagebrush (Artemisia tridentata) used to determine the variation in midwinter monoterpenoid content.

\begin{tabular}{lll}
\hline \hline Subspecies & Accession & County and state \\
\hline vaseyana & Alton & Kane, Utah \\
& Colton & Utah, Utah \\
& Sardine Canyon & Cache, Utah \\
& Benmore & Tooele, Utah \\
& Petty Bishop's Log & Sanpete, Utah \\
& Durkee Springs & Sevier, Utah \\
Salina Canyon & Sevier, Utah \\
& Clear Creek Canyon & Sevier, Utah \\
& Pinto Canyon & Washington, Utah \\
& Indian Peaks & Beaver, Utah \\
& Clear Creek Canyon & Scvicr, Utah \\
tridentata & Big Brush Creek & Uintah, Utah \\
& Loa & Wayne, Utah \\
& Dove Creek & Delores, Colorado \\
& Evanston & Uinta, Wyoming \\
& Wingate Mesa & San Juan, Utah \\
& Dog Valley & Juab, Utah \\
& Kaibab & Coconino, Arizona \\
& Trough Springs & Humboldt, Nevada \\
& Milford & Beaver, Utah \\
\hline
\end{tabular}

nal variation in monoterpenoid concentration (Nicholas 1973). Samples were stored in an ultra-low freezer $\left(-35^{\circ} \mathrm{C}\right)$ until needed for grinding and extracting.

Grinding of the vegetative samples was accomplished by placing the tissue inside the mortar of a steel, motorized mortar and pestle. Liquid nitrogen was then poured over the tissue and ground to a fine powder. After grinding, the vegetative samples were placed in plastic bottles with airtight caps and again stored at $-35^{\circ} \mathrm{C}$.

A Soxhlet extraction apparatus with absolute ether was used to extract monoterpenoids. For each sample, 10 grams of freshly ground tissue were placed in a cellulose Soxhlet extraction thimble. A fiberglass plug was placed on top of the sample inside the thimble to prevent spillover of tissue during the extraction process. Monoterpenoids were exhaustively extracted from samples over a 6-hour period. Next, the volume of the extract was reduced to about $30 \mathrm{ml}$ by use of reduced pressure. An internal standard of carvone $(2.5 \mathrm{ug} / \mathrm{ul})$ was added to each extract, then absolute ether was added to bring the volume to $50 \mathrm{ml}$. Extracts were stored in airtight bottles at $-35^{\circ} \mathrm{C}$ until needed for chromatographic analyses.

Chromatographic analyses were achieved with a $5830 \mathrm{~A}$ HewlettPackard Flame Ionization, Reporting Gas Chromatograph ${ }^{2}$. Monoterpenoids were separated by use of a $4^{\prime} \times 1 / 8^{\prime \prime}$ stainless steel column packed with $10 \%$ carbowax $20 \mathrm{~m}$ on $80 / 100$ chromosorb WHP. Temperature programming (Table 2) was used to separate individual monoterpenoids. Monoterpenoids were identified

\footnotetext{
2The use of trade, fir or cooperation name in the publication is for information and convenience of the reader. Such does not constitute an official endorsement or approval by the U.S. Department of Agriculture or of any product or service to the exclusion of others which may be suitable.
} 
Table 2. Gas chromatographic parameters used to separate and quantify individual monoterpenoids.

Initial oven temperature $\ldots \ldots \ldots \ldots \ldots \ldots \ldots \ldots \ldots \ldots, 7^{\circ} \mathrm{C}$

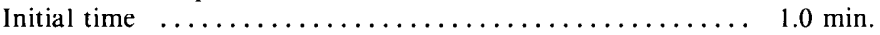

Initial temperature rate $\ldots \ldots \ldots \ldots \ldots \ldots \ldots \ldots \ldots .0^{\circ} \mathrm{C} / \mathrm{min}$.

Programmed temperature rate changes:
At $2.5 \mathrm{~min}$.
$1.0^{\circ} \mathrm{C} / \mathrm{min}$.
At $5.5 \mathrm{~min}$.
$10.0^{\circ} \mathrm{C} / \mathrm{min}$.
At $13.5 \mathrm{~min}$.
$25.0^{\circ} \mathrm{C} / \mathrm{min}$.

Final oven temperature $\ldots \ldots \ldots \ldots \ldots \ldots \ldots \ldots \ldots \ldots 0^{\circ} \mathrm{C}$

Hold at final oven temperature $\ldots \ldots \ldots \ldots \ldots \ldots \ldots \ldots \ldots, 5 \mathrm{~min}$. Flow rate ...................... $30 \mathrm{ml} / \mathrm{min}$. of $\mathbf{N}_{2}$

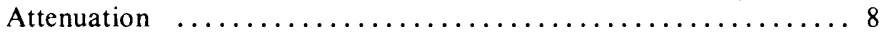

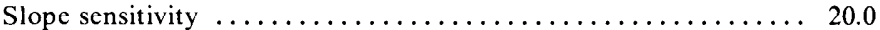

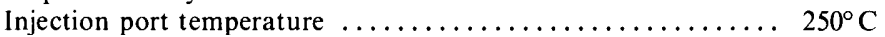
Flame ionization detector temperature $\ldots \ldots \ldots \ldots \ldots \ldots \ldots 250^{\circ} \mathrm{C}$ Maximum oven temperature $\ldots \ldots \ldots \ldots \ldots \ldots \ldots \ldots \ldots \ldots \ldots \ldots 5^{\circ} \mathrm{C}$ Area rejection mode was used to reject the solvent (absolute ether) peak.

through retention times of standards. Dry matter content of each sample was determined, and the concentration of individual monoterpenoids was expressed as a percent of dry matter.

A completely random-designed analysis of variance was used to detect significant effects due to subspecies and accessions. Hartley's multiple range test was used to compare treatment means (Snedecor and Cochran 1967).

\section{Results}

Mean monoterpenoid content for the 100 Artemisia tridentata plants was $1.73 \%$ dry matter basis (Table 3 ). The range for these individual plants was 0.36 to $3.7 \%$. Unidentified monoterpenoids made up the largest single block at $0.53 \%$. A total of 11 separate unidentifiable monoterpenoid peaks were found among the 100 chromatograms. A mean of 1.7 was the number of unidentifiable monoterpenoid peaks per plant. A number of the plants contained no unidentified peaks and one plant contained seven separate unidentified monoterpenoid peaks. Camphor $-0.37 \%$ and $\beta$ thujone- $0.37 \%$ were found to be in the highest concentration followed by $\alpha$-thujone- $0.17 \%$, terpineol $0.10 \%$, and 1,8 cineol $-0.09 \%$. These monoterpenoids contain an oxygen functional group and are therefore classified as oxygenated monoterpenes (Oh et al. 1968). About $75 \%$ of the unidentified peaks were oxygenated monoterpenes. Camphene- $0.04 \%, \alpha$-pinene- $0.3 \%$, $\alpha$-phellandrene $-0.02 \%$, and carene $-0.01 \%$ were the identified hydrocarbon monoterpenoids (the monoterpenes). About $25 \%$ of the unidentified peaks were monoterpene.

On a subspecies basis, subspecies vaseyana contained significantly higher levels of total monoterpenoids $-2.2 \%$, than did subspecies tridentata-1.4\%, and wyomingensis-1.07\% (Table 4). Subspecies wyomingensis contained significantly higher levels of camphor $-0.58 \%$ and $\alpha$-pinene- $0.08 \%$ than either vaseyana$0.35 \%, 0.02 \%$, or tridentata-0.31\%, $0.02 \%$. Subspecies vaseyana- $0.47 \%$ and tridentata $-0.41 \%$ contained significantly higher levels of $\beta$-thujone than wyomingensis $-0.01 \%$.

Subspecies vaseyana $-0.27 \%$ showed a significantly higher level of $\alpha$-thujone than tridentata- $0.09 \%$ and wyomingensis- $0.04 \%$. There were 1.2 unidentified monoterpenoid peaks per plant for able 3. Total and individual monoterpenoid content of 100 Artemisia tridentata plants grown in a uniform shrub garden. Data expressed on a percent dry matter basis.

\begin{tabular}{lcc}
\hline \hline Monoterpenoid & Percent & Percent of total oil \\
\hline$\alpha$-pinene & 0.03 & 1.7 \\
Camphene & .04 & 2.3 \\
Carene & .01 & .6 \\
$\alpha$-phelland rene & .02 & 1.2 \\
1,8 cincol & .09 & 5.2 \\
P-cymol & Trace & - \\
$\alpha$-thujone & .17 & .98 \\
$\beta$-thujone & .37 & 21.4 \\
D-camphor & .37 & 21.4 \\
Terpineol & .10 & 5.8 \\
Unknowns & .53 & 30.6 \\
$\quad$ Total & 1.73 & \\
\hline
\end{tabular}

subspecies tridentata, 1.7 for wyomingensis, and 2.2 for vaseyana. Between the solvent (absolute ether) peak and the $\alpha$-pinene peak, there was an unidentified peak that was common to all 35 subspecies tridentata plants and two of 15 wyomingensis plants. The 50 plants of subspecies vaseyana did not contain the unidentified peak.

Some accessions contained significantly higher levels of total monoterpenoids than other accessions (Table 5). An accession from Kaibab contained the lowest amount of total monoterpenoids $(0.93 \%)$. Highest levels of monoterpenoids were found in an accession from Durkee Springs-2.95\%. Accessions also varied significantly in respect to the content of individual monoterpenoids as follows:

Monoterpenoid
$\alpha$-pinene
camphene
1,8 cineol
$\alpha$-thujone
$\beta$-thujone
D-camphor
terpineol
unknowns

Percent range $0.00-0.11$ $.00-.11$ $.00-.41$ $.00-.96$ $.00-.89$ $.00-1.20$ $.00-.37$ $.05-1.19$

\section{Discussion}

Our mean monoterpenoid content of $1.73 \%$ is in line with the reports of other workers: Adams and Billinghurst (1927)-0.92\%; Kinney and Sugihara (1943)-2.2\%; Nagy et al. (1964)-1 to $2 \%$; Nagy and Tengerdy (1968) - 2 to 5\%; Sheehy (1975)-0.94\%; Dietz and Nagy (1976) - 2.5\%; and Welch and McArthur (1979)-1.9\%. Bissell et al. (1955) reported an essential oil (monoterpenoids) content of $12 \%$. Buttkus et al. (1977) reported that camphor was the major monoterpenoid accounting for 40 to $45 \%$ of the total monoterpenoids. In our study, camphor and $\beta$-thujone were the major monoterpenoids for the $100 \mathrm{~A}$. tridentata plants tested. Both compounds accounted for $42.8 \%$ of the total monoterpenoids. On an accession basis, camphor madc up $70.3 \%$ of the total monoterpenoids of the Wingate mesa accession.

Accessions from Clear Creek Canyon, Petty Bishop Log, and Salina Canyon-all vaseyana-contained no camphor. Camphor accounted for $91 \%$ of the total monoterpenoids of a single plant of the Wingate Mesa accession. Sheehy (1975) reported similar

Table 4. Total and individual monoterpenoids content among the three subspecies of $\boldsymbol{A}$ rtemisia tridentata. Data expressed on a percent dry weight basis.

\begin{tabular}{|c|c|c|c|c|c|c|c|c|c|}
\hline \multirow[b]{2}{*}{ Subspecies } & \multicolumn{9}{|c|}{ Monoterpenoids } \\
\hline & $\alpha$-pinene & Camphene & 1,8 cineol & $\alpha$-thujone & $\beta$-thujone & D-camphor & Terpineol & Unknowns & Totals \\
\hline vaseyanaI & $0.02^{\mathrm{a} 2}$ & $0.04^{\mathrm{ab}}$ & $0.10^{b}$ & $0.27^{\mathrm{b}}$ & $0.47^{\mathrm{b}}$ & $0.35^{\mathrm{a}}$ & $0.19^{b}$ & 0.73 & $2.20^{b}$ \\
\hline tridentatal & $.02^{a}$ & $.03^{\mathrm{a}}$ & $.02^{\mathrm{a}}$ & $.09^{\mathrm{a}}$ & $.41^{b} b$ & $.31^{a}$ & $.02^{a}$ & .44 & $1.40^{\mathrm{a}}$ \\
\hline wyomingensis ${ }^{I}$ & $.08^{\mathrm{b}}$ & $.08^{\mathrm{b}}$ & $.04^{\mathrm{ab}}$ & $.04^{\mathrm{a}}$ & $.01^{\mathrm{a}}$ & $.58^{\mathrm{b}}$ & $.01^{\mathrm{a}}$ & .19 & $1.07^{\mathrm{a}}$ \\
\hline
\end{tabular}

IContains trace amounts of carene, $\alpha$-phellandrene, and/or P-cymol.

${ }^{2}$ Values of individual monoterpenoid levels among the subspecies sharing the same let ter superscript are not significantly different at the $5 \%$ level. 
Table 5. Total and individual monoterpenoids content among 20 accessions of Artemisia tridentata. Data expressed on a percent dry weight basis.

\begin{tabular}{|c|c|c|c|c|c|c|c|c|c|}
\hline Accession & $\alpha$-pinene & Camphene & 1,8 cineol & $\alpha$-thujone & $\beta$-thujone & D-camphor & Terpineol & Unknowns & Totals \\
\hline Kaibab (w) & $0.11^{\mathrm{d}_{2}}$ & $0.11^{\mathrm{c}}$ & $0.02^{a}$ & $0.00^{\mathrm{a}}$ & $0.00^{\mathrm{a}}$ & $0.63^{\text {cd }}$ & $0.01^{\mathrm{a}}$ & 0.05 & $0.93^{\mathrm{a}}$ \\
\hline Clear Creek (t) & $.00^{\mathrm{a}}$ & $.00^{\mathrm{a}}$ & $.02^{\mathrm{a}}$ & $.05^{\mathrm{b}}$ & $.31^{\mathrm{b}}$ & $.24^{b c}$ & $.01^{\mathrm{a}}$ & .32 & $.95^{\mathrm{a}}$ \\
\hline Milford $(w)^{1}$ & $.05^{c}$ & $.03^{\mathrm{abc}}$ & $.01^{\mathrm{a}}$ & $.13^{\mathrm{cd}}$ & $.04^{\mathrm{a}}$ & $.22^{\mathrm{bc}}$ & $.00^{\mathrm{g}}$ & .33 & $.99^{\mathrm{a}}$ \\
\hline Wingate $(t)^{1}$ & $.04^{\mathrm{c}}$ & $.08^{\mathrm{bc}}$ & $.01^{\mathrm{a}}$ & $.02^{\mathrm{ab}}$ & $.02^{\mathrm{a}}$ & $.71^{\mathrm{cd}}$ & $.02^{\mathrm{a}}$ & .07 & $1.01^{\mathrm{a}}$ \\
\hline Big Brush $(t)$ & $.02^{\mathrm{bc}}$ & $.08^{\mathrm{bc}}$ & $.04^{\mathrm{ab}}$ & $.00^{\mathrm{a}}$ & $.06^{\mathrm{a}}$ & $.42^{\mathrm{bc}}$ & $.02^{\mathrm{a}}$ & .38 & $1.02^{\mathrm{a}}$ \\
\hline Colton (v) & $.01^{\mathrm{b}}$ & $.01^{\mathrm{ab}}$ & $.01^{\mathrm{a}}$ & $.02^{\mathrm{ab}}$ & $.48^{b c}$ & $.15^{\mathrm{b}}$ & $.00^{a}$ & .34 & $1.02^{\mathrm{a}}$ \\
\hline Trough Sp. (w) & $.09^{\mathrm{d}}$ & $.09^{\mathrm{bc}}$ & $.08^{\mathrm{bc}}$ & $.00^{\mathrm{a}}$ & $.00^{\mathrm{a}}$ & $.89^{d}$ & $.02^{\mathrm{a}}$ & .24 & $1.41^{\mathrm{ab}}$ \\
\hline Dog Valley $(t)$ & $.02^{\mathrm{bc}}$ & $.02^{\mathrm{abc}}$ & $.01^{\mathrm{a}}$ & $.24^{\mathrm{d}}$ & $.33^{\mathrm{b}}$ & $.26^{\mathrm{bc}}$ & $.03^{\mathrm{a}}$ & .60 & $1.51^{\mathrm{ab}}$ \\
\hline Pinto Canyon (v) & $.04^{\mathrm{c}}$ & $.08^{\mathrm{bc}}$ & $.06^{\mathrm{b}}$ & $.04^{\mathrm{b}}$ & $.01^{\mathrm{a}}$ & $.54^{\mathrm{cd}}$ & $.37^{\mathrm{b}}$ & .29 & $1.63^{\mathrm{ab}}$ \\
\hline Evanston $(t)$ & $.01^{\mathrm{b}}$ & $.00^{a}$ & $.00^{\mathrm{a}}$ & $.09^{\mathrm{bc}}$ & $.89^{d}$ & $.13^{\mathrm{b}}$ & $.01^{\mathrm{a}}$ & .53 & $1.66^{\mathrm{ab}}$ \\
\hline Dove Creek $(t)$ & $.00^{\mathrm{a}}$ & $.00^{\mathrm{a}}$ & $.02^{\mathrm{a}}$ & $.07^{\mathrm{bc}}$ & $.71^{\mathrm{bc}}$ & $.13^{\mathrm{b}}$ & $.00^{\mathrm{a}}$ & .77 & $1.70^{\mathrm{bc}}$ \\
\hline Indian Peaks (v) & $.00^{\mathrm{a}}$ & $.04^{\mathrm{abc}}$ & $.12^{\mathrm{c}}$ & $.03^{\mathrm{ab}}$ & $.02^{\mathrm{a}}$ & $.31^{\mathrm{bc}}$ & $.01^{\mathrm{a}}$ & 1.19 & $1.72^{\mathrm{bc}}$ \\
\hline Sardine (v) & $0.02^{\mathrm{bc}}$ & $.11^{c}$ & $.06^{\mathrm{b}}$ & $.25^{\mathrm{d}}$ & $.58^{\mathrm{c}}$ & $.62^{\text {cd }}$ & $.05^{\mathrm{ab}}$ & .05 & $1.74^{\mathrm{bc}}$ \\
\hline Clear Creek (v) & $.00^{\mathrm{a}}$ & $.00^{\mathrm{a}}$ & $.09^{c}$ & $.00^{\mathrm{a}}$ & $.75^{\mathrm{cd}}$ & $.00^{\mathrm{a}}$ & $.18^{\mathrm{ab}}$ & .80 & $1.82^{\mathrm{bcd}}$ \\
\hline Loa $(t)$ & $.01^{\mathrm{b}}$ & $.03^{\mathrm{abc}}$ & $.09^{c}$ & $.13^{\mathrm{cd}}$ & $.55^{\mathrm{c}}$ & $.28^{\mathrm{bc}}$ & $.05^{\mathrm{ab}}$ & .76 & $1.91^{\mathrm{cd}}$ \\
\hline Alton $(v)^{1}$ & $.04^{c}$ & $.07^{b c}$ & $.11^{\mathrm{c}}$ & $.01^{\mathrm{a}}$ & $.29^{b}$ & $.58^{\mathrm{ed}}$ & $.19^{\mathrm{ah}}$ & .69 & $2.03^{\text {ed }}$ \\
\hline Petty Bishop (v) & $.00^{\mathrm{a}}$ & $.00^{\mathrm{a}}$ & $.01^{\mathrm{a}}$ & $.74^{\mathrm{e}}$ & $.60^{\mathrm{c}}$ & $.00^{\mathrm{a}}$ & $.33^{b}$ & .88 & $2.58^{\mathrm{d}}$ \\
\hline Salina $(v)^{1}$ & $.00^{\mathrm{a}}$ & $.00^{\mathrm{a}}$ & $.02^{\mathrm{a}}$ & $.63^{\mathrm{c}}$ & $.47^{b c}$ & $.00^{\mathrm{a}}$ & $.31^{\mathrm{b}}$ & 1.12 & $2.60^{\mathrm{d}}$ \\
\hline Benmore $(v)^{1}$ & $.00^{\mathrm{a}}$ & $.00^{\mathrm{a}}$ & $.09^{\mathrm{c}}$ & $.96^{\mathrm{f}}$ & $.49^{\mathrm{bc}}$ & $.05^{\mathrm{ab}}$ & $.32^{\mathrm{b}}$ & .90 & $2.89^{d}$ \\
\hline Durkee Springs $(v)^{1}$ & $.05^{c}$ & $.08^{\mathrm{bc}}$ & $.41^{\mathrm{d}}$ & $.00^{\mathrm{a}}$ & $.85^{\mathrm{d}}$ & $1.20^{\mathrm{d}}$ & $.16^{\mathrm{ab}}$ & .12 & $2.95^{\mathrm{d}}$ \\
\hline
\end{tabular}

Contains trace amounts of carene, $\alpha$-phellandrene, and/or P-cymol.

${ }^{2}$ Values of individual monoterpenoid levels among the accessions sharing the same letter superscript are not significantly different at the $1 \%$ level

$(\mathrm{w})=$ Artemisia tridentata $\mathrm{ssp}$. wyomingensis

$(t)=$ Artemisia tridentata ssp. tridentata

(v) = Artemisia tridentata ssp. vaseyana

results. He found that camphor accounted for 4.2 to $63.8 \%$ of the total monoterpenoids among the four taxa of $\boldsymbol{A}$. tridentata tested. Scholl (1976) reported that for the taxa of $A$. tridentata he studied, camphor accounted for 30 to $50 \%$ of the monoterpenoids.

Powell (1970) noted a marked variation in monoterpenoid content among $\boldsymbol{A}$. tridentata plants from different sites. We believe that at least part of this variation was due to genetic differences rather than to site differences. We base our beliefs on our findings that some accessions of $\boldsymbol{A}$. tridentata, when grown in a uniform environment, were significantly higher in monoterpenoids than others. Sheehy (1975) reported similar results and conclusions. He found that for samples collected in December, subspecies tridentata contained the highest level of monoterpenoids followed by vaseyana and wyomingensis. For samples collected in March, subspecies vaseyana contained the highest level of monoterpenoids followed by subspecies tridentaia and wyomingensis. Sheehy (1975) also observed that he monoterpenoid levels peaked in December and were lowest in May. Our one-point-in-time analysis (mid-January) agrees with Sheehy's March sampling. We found that subspecies vaseyana $(2.2 \%)$ contained significantly higher levels of monoterpenoids than subspecies tridentata $(1.40 \%)$, and wyomingensis (1.07\%).

Our interest in the monoterpenoid content of $A$. tridentata stemmed from the re'port of Nagy et al. (1964) that, in high concentrations, these compounds may affect digestion in mule deer. Oh et al. $(1967,1968)$ found that monoterpenoid hydrocarbons (the monoterpenes) of Douglas-fir needles ( $\alpha$ pinene, $\beta$-pinene, limonene, myrcene, camphene, $\Delta^{3}$-carene, and terpinolene) actually enchanced in vitro microbial fermentation of sheep and deer rumen microorganisms. Sesquiterpenes were also found to be stimulatory. Oxygenated monoterpenoids (alcohols, esters, and aldehydes), however, inhibited microbial fermentation (Oh et al. 1967, 1968; and Longhurst et al. 1969).

Nagy et al. (1964) calculated that $A$. tridentata could constitute from 15 to $30 \%$ of mule deer diet without impairing digestion. They also suggested that rumen microorganisms may be able to adapt to $A$. tridentata monoterpenoids. The idea that rumen microorganisms can adapt to monoterpenoids (especially oxygenated monoterpenoids) is supported by the observations made by Oh et al. (1967). They found that citonellal, an oxygenated monoterpenoid (aldehyde), inhibited rumen microorganisms from sheep and deer having no access to Douglas-fir (a monoterpenoid source), but produced no effect upon rumen microorganisms from deer having access to Douglas-fir.

Neither in vitro nor in vivo digestibility trials of $A$. tridentata support the contention that monoterpenoids are interfering with the digestion of mule deer (Smith 1950, Bissell et al. 1951; Smith 1952; Smith 1957; Dietz et al. 1962; Regelin et al. 1974; Sheehy 1975; Urness et al. 1977; Wallmo et al. 1977; and Welch and McArthur 1979). In vitro dry matter digestibility of $A$. tridentata was the highest of all shrub species tested (Table 6). Even after correcting for monoterpenoids, $A$. tridentata was second only to aspen in the amount of dry matter digested; however, caution must be used in drawing inference from the data presented in Table 6. Wallmo et al. (1977) and Sheehy (1975) used preparatory techniques that could have resulted in large losses of monoterpenoids from their samples, thus introducing bias. In vivo digestibility trials of $A$. tridentata showed that for mule deer, $\boldsymbol{A}$. tridentata ranked second only to curlleaf mahogany in total

Table 6. In vitro digestibility of shrub dry matter by mule deer inoculum.

\begin{tabular}{lll}
\hline \hline Shrub & $\begin{array}{l}\text { Dry matter } \\
\text { digestibility percent }\end{array}$ & Reference \\
\hline Big sagebrush & $58.456 .4^{2}$ & $3,4,5$ \\
Aspen & 57.4 & 1 \\
Rose & 54.5 & 1 \\
Serviceberry & 54.4 & 1 \\
Curlleaf mahogany & 53.5 & 4 \\
Chokecherry & 51.3 & 1 \\
Russet buffaloberry & 49.6 & 2 \\
Willow & 46.5 & 2 \\
Snowberry & 41.0 & 1 \\
Blueberry & 33.3 & 2 \\
Bitterbrush & 30.0 & 4 \\
Mountain mahogany & 28.5 & 4 \\
\hline
\end{tabular}

1Reference:

1. Dietz 1972

2. Regelin et al. 1974

3. Sheehy 1975

4. Urness et al. 1977

5. Wallmo et al. 1977

${ }^{2}$ Corrected value for monoterpenoids. This value was calculated by subtracting the monoterpenoid content at $2.0 \%$. 
Table 7. In vivo digestibility of shrubs by mule deer.

\begin{tabular}{lll}
\hline \hline Shrub & $\begin{array}{c}\text { TDN1 } \\
\%\end{array}$ & Reference $^{2}$ \\
\hline Curlleaf mahogany & 64.8 & $3,4,6$ \\
Big sagebrush & $63.458 .9^{3}$ & $1,2,4,5,6$ \\
Mountain mahogany & 48.4 & $4,5,6$ \\
Cliffrose & 47.2 & 4 \\
Bitterbrush & 46.0 & $2,3,4,5,6$ \\
Chokecherry & 38.9 & 4 \\
Oak & 36.2 & 4 \\
\hline
\end{tabular}

Total digestible nutrients

2Reference:

1. Smith 1950

2. Bissell et al. 1955

3. Smith 1952

4. Smith 1957

5. Dietz et al. 1962

6. Urness et al. 1977

${ }^{3}$ Corrected TDN value for essential oils. This value was calculated by taking the content of essential oils $(2.0 \%)$ and multiplying this value by the fat energy factor $(2.25)$. The resultant (4.5) is subtracted from the TDN valuc.

digestible nutrients (Table 7). Even after correcting for monoterpenoids, $A$. tridentata still ranked second (Table 7).

Smaller amounts of monoterpenoids were probably lost from the $A$. tridentata tissues fed to deer than were lost during in vitro trials. Smith (1950) and Bissell et al. (1951) provided freshly cut $A$. tridentata - with unground stems and leaves - to their deer on a daily basis. None of these in vivo trials supports the hypothesis that monoterpenoids interfere with digestion.

We are not sure that the monoterpenoids in $A$. tridentata are causing digestive problems in mule deer. Evidence in the literature we have cited can be used to argue both sides of the question. We believe that Wallmo et al. (1977) and Dietz and Nagy (1976) and premature in claiming that the monoterpenoids in $A$. tridentata are toxic to mule deer-more research is needed. We will be studying the in vitro digestibility of nine accessions of $A$. tridentata grown in a uniform environment. Samples will be prepared without loss of monoterpenoids. Also, we will be measuring the levels of monoterpenoids in the ingesta of the rumen, reticulum, omasum, abomasum, and internal pellets in the large intestine. These levels of monoterpenoids will be related to the amounts found in the vegetation consumed by the wintering mule decr. From these studies, we should be able to decide the necessity of selecting for low total monoterpenoid of for certain monoterpenoids as a means of developing superior strains of $A$. tridentata for use on mule deer winter ranges.

During digestibility trials, Smith (1950) noted that deer showed definite aversion to individual $A$. tridentata plants. This differential preference of mule deer for certain accessions and individual plants of $A$. tridentat $a$ has been observed in the field by a number of researchers (Plummer et al. 1968, Winward 1970, Hanks et al. 1971, Stevens and McArthur 1974, Sheehy 1975, Scholl et al. 1977, McArthur 1979). Recently two attempts have been made to relate monoterpenoid content of Artemisia ssp. to accessional differences in preference. Sheehy (1975) reported that relative concentration of eight monoterpenoids could account for $90 \%$ of the variation of mule deer utilization among seven sagebrush taxa. Only two of these monoterpenoids had a negative influence on mulc deer utilization- $\alpha$-pinene and an unknown. Scholl et al. (1977) using the relative concentration of eight monoterpenoids could account for only $20.7 \%$ variation of mule deer utilization among 12 sagebrush taxa. Nagy and Regelin (1977) hypothesized that $A$. nova is preferred over $A$. tridentata by deer. They base their hypothesis on two points: first, $A$. nova contains about $50 \%$ less monoterpenoids than $A$. tridentata; and second, $A$. nova monoterpenoids interfere less with digestion. Smith (1950) found, however, that "big sage was much preferred to black sage," and Sheehy (1975) reported similar results in his study. Both Stevens and McArthur (1974) and Scholl et al. (1977) reported that some accessions of $A$. nova are preferred over others by the consuming mule deer. As with digestion, we are not sure what role monoterpenoids are playing in palatability. We will, in the future, be conducting tests on 21 accessions of $A$. tridentata to determine the necessity of selecting for low total monoterpenoids or for certain monoterpenoids as a means of developing superior strains of $A$. tridentata for use on mule deer winter ranges.

If future studies show that monoterpenoids of $A$. tridentata interfere with digestion or have a negative impact on palatability, we can-if needed-develop breeding and selection schemes to capitalize on the significant differences in monoterpenoids that exist among accessions of $A$. tridentata grown in a uniform environment.

\section{Literature Cited}

Adams, M., and R. Billinghurst. 1927. Essential oils in desert plants. I. Physical constants. J. Amer. Chem. Soc. 49:2895-2897.

Beetle, A.A., and A. Young. 1965. A third subspecies in the Artemisia tridentata complex. Rhodora 67:405-406.

Bissell, H.D., B. Harris, H. Strong, and F. James. 1955. The digestibility of certain natural and artificial foods eaten by deer in California. California Fish and Game 41:57-78.

Buttkus, H.A., R.J. Bose, and D.A. Shearer. 1977. Terpenens in the essential oil of sagebrush (Artemisia tridentata). Agr. and Food Chem. 25:288-291.

Dietz, D.R. 1972. Nutritive value of shrubs. In: Wildland Shrubs-Their Biology and Utilization. p. 289-302. C.M. McKell, J.P. Blaisdell, and J.R. Goodin (eds.). U.S. Dep. Agr. Forest Serv. Gen. Tech. Rep. INT-I. Intcrmt. Forest and Range Exp. Sta., Ogden, Utah.

Dietz, D.R., R.H. Udall, and L.E. Yeager. 1962. Chemical composition and digestibility by mule deer of selected forages species, Cache la Poudre Range, Colorado. Colorado Fish and Game Dep. Tech. Pub. 14:76.

Dietz, D.R., and J.G. Nagy. 1976. Mule deer nutrition and plant utilization In: Mule Deer Decline in the West-A Symposium. p. 71-78. G.W. Workman, and J.B. Low (eds). Coll. Natur. Resour. Utah Agr. Exp. Sta., Logan.

Hanks, D.L., J.R. Brunner, D.R. Christensen, and A.P. Plummer. 1971. Paper chromatography for determining palatability differences in various strains of big sagebrush. U.S. Dep. Agr. Forest Serv. Res. Pap. INT-101. 9 p

Kinney, C.R., and J. Sugihara. 1943. Constituents of Artemisia tridentata (American sagebrush). J. Org. Chem. 8:290-294.

Longhurst, W.M., J.H. Oh, M.B. Jones, and R.E. Kepner. 1969. Deer forage palatability, digestibility, and management implications. Paper given: California-Nevada sect., Wildl. Soc. Annu. Meetings, Feb. 1, 1969, Berkeley, Calif.

McArthur, E.D. 1979. Sagebrush systematics and evoluation. In: Sagebrush Ecosystem Symposium, p. 14-22. G.F. Gifford, F.E. Busby, and J.P. Shaw (eds.). Coll. Natur. Resour. Utah Agr. Exp. Sta., Logan, Utah. 251 p.

McArthur, E.D., A.C. Blauer, A.P. Plummer, and R. Stevens. 1979. Characteristics and hybridization of important Intermountain shrubs. III. Sunflower family. U.S. Dep. Agr. Forest Serv. Res. Pap. INT-220, 82 p.

Maynard, L.A., and J.K. Loosli. 1962. Animal Nutrition. p. 59-60. McGraw-Hill Book Co., New York. 533 p.

Nagy, J.G., and W.L. Regelin. 1977. Influence of plant volatile oils on food selection by animals. XIIIth Congress of Game Biologists 13:225-230.

Nagy, J.G., H.W. Steinhoff, and G.M. Ward. 1964. Effects of essential oils of sagebrush on deer rumen microbial function. J. Wildl. Manage. 28:785-790.

Nagy, J.G., and R.P. Tengerdy. 1968. Antibacterial action of essential oils of Artemisia as an ecological factor. II. Antibacterial action of the volatile oils of Artemisia tridentata (big sagebrush) on bacteria from the rumen of mule deer. Appl. Microbiol. 16:441-444.

Nicholas, H.J. 1973. Terpenes. In: Phytochemistry Vol. II. Organic Metabolites. p. 254-309. L.P. Miller (ed.). Van Nostrand Reinhold Company, New York and Cincinnati.

Oh, H.K., T. Sakai, M.B. Jones, and W.M. Longhurst. 1967. Effects of various essential oils isolated from Douglas-fir ncedles upon sheep and deer rumen microbial activity. Appl. Microbiol. 15:777-784.

Oh, H.K., M.B. Jones, and W.M. Longhurst. 1968. Comparison of rumen microbial inhibition resulting from various essential oils isolated from relatively unpalatable plant species. Appl. Microbiol. 16:39-44. 
Plummer, A.P., D.R. Christensen, and S.B. Monsen. 1968. Restoring big game range in Utah. Utah Div. Fish and Game Pub. 68-3, 183 p.

Powell, J. 1970. Site factor relationship with volatile oils in big sagebrush. J. Range Manage. 23:42-46.

Regelin, W.L., O.C. Wallmo, J.G. Nagy, and D.R. Dietz. 1974. Effects of logging on forage values for deer in Colorado. J. Forest. 72:282-287.

Scholl, J.P. 1976. Volatile compounds of Artemisia section Tridentatae (sagebrush): A study in plant untilization by mule deer. M.S. Thesis. Univ. Montana, Missoula, $93 \mathrm{p}$.

Scholl, J.P., R.G. Kelsey, and Fred Shafizadeh. 1977. Involvement of volatile compounds of Artemisia in browse preference by mule deer. Biochem. Sys. and Ecol. 5:291-295.

Sheehy, D.P. 1975. Relative palatability of seven Artemisia taxa to mulc deer and sheep. M.S. Thesis, Oregon State Univ., Corvallis, 147 p.

Smith, A.D. 1950. Sagebrush as winter feed for mule deer. J. Wildl. Manage. 14:285-289.

Smith, A.D. 1952. Digestibility of some native forages for mule deer. J. Wildl. Manage. 16:309-312.

Smith, A.D. 1957. Nutritive value of some browse plants in winter. J. Range Managc. 10:162-164.
Snedecor, G.W., and W.G. Cochran. 1967. Statistical Methods. The Iowa State Univ. Press, Ames, lowa. 593 p.

Stevens, R., and E.D. McArthur. 1974. A simple field technique for identification of some sagebrush taxa. J. Range Manage. 27:325-326.

Urness, P.J., A.D. Smith, and R.K. Watkins. 1977. Comparison of in vivo and in vitro dry matter digestibility of mule deer forages. J. Range Manage. 30:119-121.

Wallmo, O.C., L.H. Carpenter, W.L. Regelin, R.B. Gill, and D.L. Baker. 1977. Evaluation of deer habitat on a nutritional basis. J. Range Manage. 30: 122-127.

Welch, B.L., and E.D. McArthur. 1979. Feasibility of improving big sagebrush (Artemisia tridentata) for use on mule deer winter ranges. In: p. 451-473 Proceedings of the International Arid Lands Conference on Plant Resources, J.R. Goodin and D.K. Northington (eds.). Texas Tech Univ., Lubbock.

Winward, A.H. 1970. Taxonomic and ecological relationships of the big sagebrush complex in Utah. Ph.D. Diss., Univ. Idaho, Moscow. 80 p.

Winward, A.H., and E.W. Tisdale. 1977. Taxonomy of the Artemisia tridentata complex in Idaho. Coll. Forest Wildl., and Range Sci., Univ. Idaho, Moscow, Bull. 19. 15 p. 